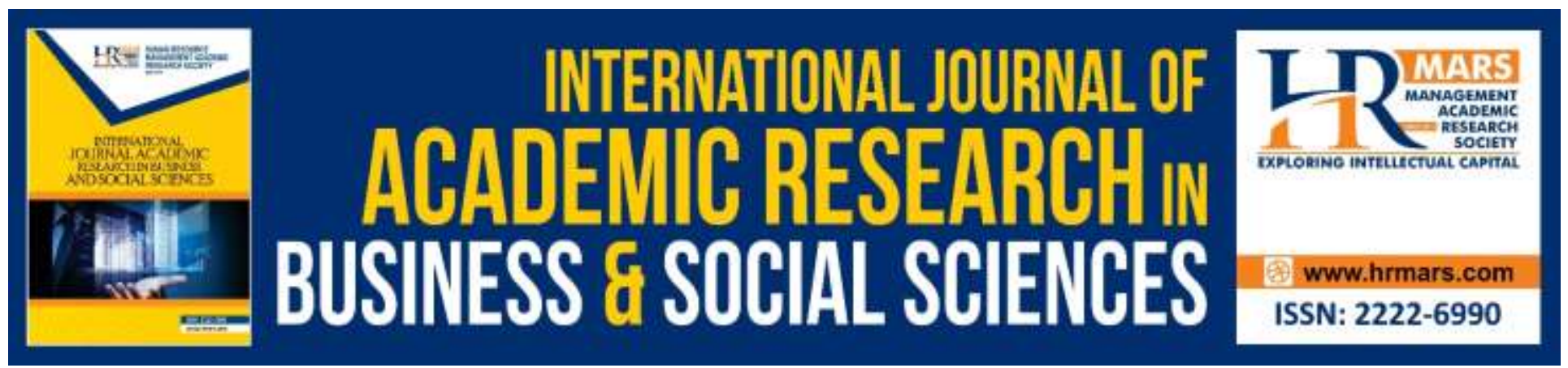

\title{
The Relationship between Communication Apprehension and the Graduates Choice of Entrepreneurship as a Career
}

Noorkartina Mohamad and Mai Syaheera M. Shaari

To Link this Article: http://dx.doi.org/10.6007/IJARBSS/v9-i6/6073

DOI: $10.6007 /$ IJARBSS/v9-i6/6073

Received: 02 April 2019, Revised: 15 May 2019, Accepted: 02 June 2019

Published Online: 27 June 2019

In-Text Citation: (Mohamad \& Shaari, 2019)

To Cite this Article: Mohamad, N., \& Shaari, M. S. M. (2019). The Relationship between Communication Apprehension and the Graduates Choice of Entrepreneurship as a Career. International Journal of Academic Research in Business and Social Sciences, 9(6), 1121-1127.

Copyright: (C) 2019 The Author(s)

Published by Human Resource Management Academic Research Society (www.hrmars.com)

This article is published under the Creative Commons Attribution (CC BY 4.0) license. Anyone may reproduce, distribute, translate and create derivative works of this article (for both commercial and non-commercial purposes), subject to full attribution to the original publication and authors. The full terms of this license may be seen at: http://creativecommons.org/licences/by/4.0/legalcode

Vol. 9, No. 6, 2019, Pg. 1121 - 1127

Full Terms \& Conditions of access and use can be found at http://hrmars.com/index.php/pages/detail/publication-ethics 


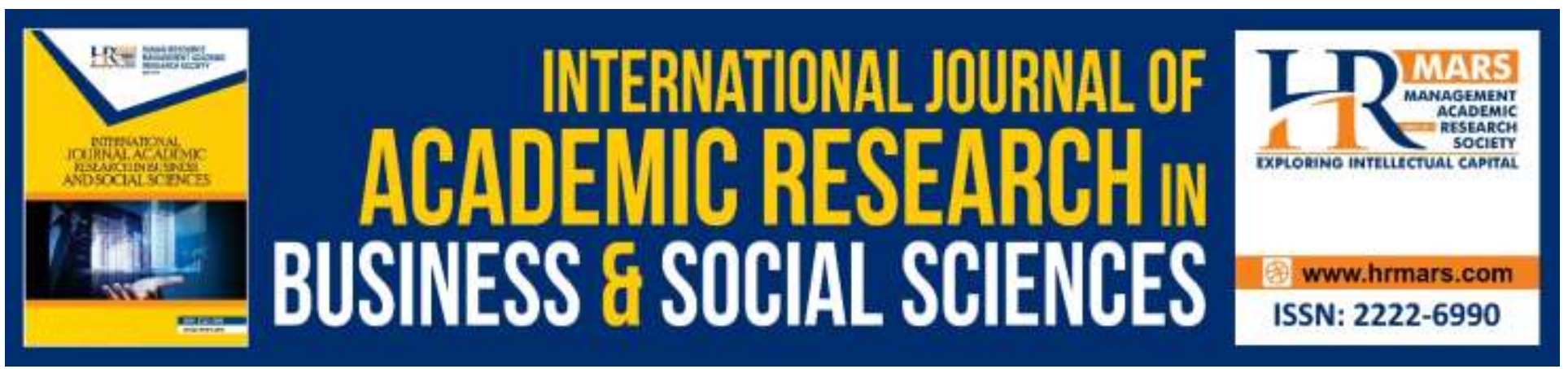

\title{
The Relationship between Communication Apprehension and the Graduates Choice of Entrepreneurship as a Career
}

\author{
Noorkartina Mohamad and Mai Syaheera M. Shaari \\ Faculty of Management and Muamalah, Islamic University College of Perlis
}

\begin{abstract}
The purpose of this study is to look at the relationship between the choice of entrepreneurship as a career and communication apprehension. This study poses a question: Will a graduate who could not become employed due to his/her lack of communication skills choose to become an entrepreneur? Researchers agree that one of the main skill to become an entrepreneur is communication skills. A survey is conducted among 2300 graduates from Universiti Utara Malaysia (UUM). The choice to become an entrepreneur refers to graduates who are self-employed. In addition to being selfemployed (entrepreneur), there are other employment states such as unemployed, employed fulltime and not full-time employed. In this context, the choice set could be expanded to more than two categories: self-employed (entrepreneur), unemployed, employed full-time, and not full-time employed. The findings will help to identify the existence in relationship between the choice of entrepreneurship as a career and communication apprehension.
\end{abstract}

\section{Introduction}

Presently, a reasonable academic qualification is no longer a guarantee for securing employment among Malaysian graduates (Azina, 2011). Although it serves as an advantage for graduates, it does not promise employment and does not even substantiate that these graduates can execute the tasks assigned by their employers. According to Rahmah et al., (2011), one of the reasons for the issue of joblessness among Malaysian graduates is the quality of these graduates.

Communication skill is considered as one of the important skills needed to be developed by graduates especially to find an opportunity in paid jobs (Shuib, 2005). Most of employers are concerned about the levels of communication skill in group discussion, conducting meeting, interpersonal skills and also skills of public speaking in their organizations (Azleen et al., 2013). Lacking in communications skills will be a barrier for those who are poor in these skills to get a job (Blume et al., 2013). 
A study by Amirul (2014) reported that only 7 out of 300 Malaysian graduates are able to communicate effectively during interview sessions. Kamsah (2004) in her findings also found that most of graduates have poor communication skills during the process of interview. Lack of communication skill is due to fear, anxiety and having less confidence, when an individual communicates with other people and this feeling refers to communication apprehension (McCroskey et al., 1985).

Graduates with low communication skills will have limited choices in terms of career options especially in paid job (Azleen et al., 2013; Blume et al., 2013; Muhd Amirul, 2014; Kamsah, 2004). Thus, it is imperative to estimate the effects of communication apprehension in choosing to be entrepreneurs among the graduates.

\section{Literature Review}

The rapid changes in the industrial environment have led to changes in employment requirements (Agarwala, 2008). Graduates should not only have excellent academic qualifications, they must also be equipped with added values such as independence and having a competitive spirit, a pleasant appearance, and good generic skills (Agarwala, 2008). Employers nowadays have their sights set beyond academic qualifications. They seek employees with interesting personalities and other added values (Morshidi et al., 2011; Lim \& Muszafarshah, 2013; Lim \& Normizan, 2004; Lim, 2007; Lim, 2010; Lim, 2011). Good communication skills support other added values (Morshidi et al., 2011; Lim and Muszafarshah, 2013; Lim and Normizan, 2004; Lim, 2007; Lim, 2010; and Lim, 2011). Good communication skills help employees to conduct themselves well in complicated working situations (Mohd Sahandri \& Saifuddin, 2009; Yassin et al., 2008; and Nabi \& Bagley, 1998). Even the Australian Chamber of Commerce has ascertained that professional workers are required to have proficiency in a variety of generic skills (Mohd Sahandri \& Saifuddin, 2009).

Communicative skill is defined by Lans et al., (2004) as the proficiency in communication that is needed by entrepreneurs to interact with varying stakeholders. Each step of business development requires good communication, especially during the initial stages of entrepreneurship (Holt \& Macpherson, 2010; Lee \& Jones, 2008; Roodt, 2005). Baron (2007) categorized it as a type of social skill and further divided it into four: (1) social perception-being able to accurately perceive people; (2) impression management-being able to make a good first impression; (3) expressiveness - being able to clearly and openly express emotions; and (4) social adaptability-being able to proficiently adapt actions to the current social context.

However, in actual situations, Azleen et al., (2013) found that graduates are not only nervous during interviews, they also lack the confidence and communication skills that would help win the job. Byron (2005) earlier stated that university graduates who step into the employability market are still having difficulties in communicating proficiently. Much is known about the importance of communication skills, but little is known about how students actually face difficulties in their efforts to improve their skills (Stanga \& Ladd, 1990). The main hurdle is known as communication apprehension (CA) (Hassall 
et al., 2000). CA is a type of fear that hinders a person from communicating with others and this fear affects his/her abilities in succeeding and achieving satisfaction in the job (McCroskey, 2005).

High apprehension in communication leads to low job satisfaction as a result of the negative tendencies, such as tenseness, that arise from it (McCroskey et al., 1976). People with high CA have a fear to communicate, which causes them to become quieter because people naturally avoid doing what they are afraid to do (Richmond \& McCroskey, 1989). Hence, people with high CA tend to choose jobs such as working with computers, which do not require them to communicate a great deal (Daly \& McCroskey, 1975). In contrast, people with low CA prefer jobs that allow them to communicate to a greater extent.

Even without good communication skills, graduates may still survive by creating their own jobs and becoming self-employed through entrepreneurship. According to Agarwala (2008), there are two options in choosing a career: (1) the availability of other alternatives; and (2) personal priority towards the career. In case of Malaysian graduates, Zarina et al., (2011) stated that individual who are less proficient in English language will increase his/her communication apprehension during the interview session and choose to be an entrepreneur as an alternative, after fail to obtain paid employment in the job market. Thus, in this study, the alternative career for individuals with low communication skills is to become entrepreneurs.

Thus, this study poses a question:

R1: Will a graduate who could not become employed due to his/her lack of communication skills choose to become an entrepreneur?

R2: Is it the factor of higher in communication apprehension will transform graduates become an entrepreneur?

Researchers agree that one of the main characteristics of an entrepreneur is good communication skills (Clarke \& Cornelissen, 2011; Stracke \& Kumar, 2014; Azleen et al., 2013; Davidson \& Honig, 2003; Siegal \& Sorenson, 1994). For that reason, it seems that the real-life situation (graduates with low communication skills tend to choose entrepreneurship due to career limitations) is contradictory with the common perception (entrepreneurs must have good communication skills). Past studies clearly state that graduates with low communication skills have difficulties in getting employed. However, few studies relate low communication skills to choosing entrepreneurship as an alternative after failing to get a job for the same reason. Hence, this study aims to determine the relationship between the level of communication apprehension, and the graduates' choice of entrepreneurship as a career.

\section{The Effects of Communication Apprehension}

The result of the study shows that there are positive significant effects between communication apprehension in terms of group discussion and probability of being an entrepreneur (as compared to being unemployed). The result is significant at the 5 percent level of significance. This result implies 
that respondents who have high communication apprehension are more likely to be an entrepreneur compared to those who have lower communication apprehension. Quantitatively, the marginal effects show that respondents who had poor communication were 0.1 percentage points more likely to be an entrepreneur compared to respondents who had higher communication apprehension. Relatively, the effect of communication apprehension is highest when the probability of becoming an entrepreneur is comparable with the probability of being unemployed (estimated coefficient, 0.044).

However, there are negative significant effects between communication apprehension in terms of meeting skills and respondents' actual choice to be an entrepreneur at the 5 percent level of significance. The result implies that respondents who have lower communication apprehension are less likely to be an entrepreneur compared to those who have higher communication apprehension. Quantitatively, the marginal effects show that respondents who had lower communication apprehension were 0.2 percentage points less likely to be an entrepreneur compared to respondents who had higher communication apprehension. Relatively, the effect of communication apprehension is lowest when the probability of becoming an entrepreneur is 174 comparable with the probability of being not full-time employed (estimated coefficient, -0.083 ).

Communication apprehension in terms of public speaking had a positive significant effect on the probability of being an entrepreneur (as compared to being not full-time employed) and this is significant at the 5 percent level of significance. This result implies that respondents who have higher communication apprehension are more likely to be an entrepreneur compared to those who have lower communication apprehension. Quantitatively, the marginal effects show that respondents who had higher communication apprehension were 0.1 percentage points more likely to be an entrepreneur compared to respondents who had lower communication apprehension. Relatively, the effect of communication apprehension is highest when the probability of becoming an entrepreneur is comparable with the probability of being not full-time employed (estimated coefficient, 0.051).

\section{Conclusion}

Communication skill is considered as one of the important skills needed to be developed by graduates especially to find an opportunity in paid jobs (Shuib, 2005). This study focus on the relationship between the choice of entrepreneurship as a career and communication apprehension. The result of the study shows that communication has a huge role in getting a job. Communication apprehension and entrepreneurship highly related to each other. In these studies it shows that high communication apprehension is more likely to be an entrepreneur compared to those who have lower communication apprehension. Thus, within the context of graduates' entrepreneurship in Malaysia, the findings can be said to have contribution to the literature and future research in various way. 
INTERNATIONAL JOURNAL OF ACADEMIC RESEARCH IN BUSINESS AND SOCIAL SCIENCES

Vol. 9, No. 6, June, 2019, E-ISSN: 2222-6990 @ 2019 HRMARS

\section{References}

Agarwala, T. (2008). Factors influencing career choice of management students in India. Career Development International, 13(4), 362-376.

Azleen, I., Mohd Zulkeflee, A. R., \& Nek Kamal, Y. Y. (2013). Communication apprehension (CA): A case of accounting students. International Journal of Independent Research and Studies, 2(1), 16-27.

Baron, R. A. (2007). Behavioral and cognitive factors in entrepreneurship Entrepreneurs as the active element in new venture creation. Strategic Entrepreneurship Journal, 1, 167-182.

Blume, D. B., Baldwin, T. T., \& Ryan, C. K. (2013). Communication apprehension: A barrier to students' leadership, adaptability and multicultural appreciation. Academy of Management Learning \& Education, 12(2), 158-172

Byron, A., L. (2005). Communication apprehension in the workplace and its effects on employee job satisfaction. (Unpublished doctoral dissertation). Texas Tech University.

Clarke, J., \& Cornelissen, J. (2011). Language, communication and socially situated cognition in entrepreneurship. Academy of Management Review, 34(3), 776-778.

Daly, J. A., \& McCroskey, J. C. (1975). Occupational desirability and choice as a function of communication apprehension. Journal of Counseling Psychology,22, 309-313.

Holt, R., \& Macpherson, A. (2010). Sensemaking, rhetoric and the socially competent entrepreneur. International Small Business Journal, 28(1), 20-42

Kamsah, M. Z. (2004, December). Developing generic skills in classroom environment: Engineering student' perspective. Paper presented at Conference On Engineering Education (CEE 2004), Kuala Lumpur, Malaysia.

Lans, T., Wesselink, R., Biemans, H. J., \& Mulder, M. (2004). Work-related lifelong learning for entrepreneurs in the agri-food sector. International Journal of Training and Development, 8(1), 73-89.

Lee, R., \& Jones, O. (2008). Networks, communication and learning during business start-up: The creation of cognitive social capital. International Small Business, 26(5), 559-594

Lim, H. E. (2007). Estimating the employability performance indicator: The case of Universiti Utara Malaysia graduates. Singapore Economic Review, 52(1),73-91.

Lim, H. E. (2010). Estimating psychological impact of unemployment: The case of Malaysian graduates. Malaysian Journal of Economic Studies, 47(1), 33-53.

Lim, H. E. (2011). The determinants of individual unemployment duration: The case of Malaysian graduates. Journal of Global Management, 2(2), 184-203.

Lim, H. E., \& Muszafarshah, M. M. (2013). Effectiveness of industrial training in improving student's generic skills: An exploratory study. International Journal of Business and Society, 14(3), 418423.

McCroskey, J. C., Beatty, M. J., Kearney, P., \& Plax, T. G. (1985). The content validity of the PRCA-24 as a measure of communication apprehension across communication contexts. Communication Quarterly, 33(3), 165-173.

McCroskey, J., C., \& Wheeless, L., R. (1976). Introduction to human communication. Boston: Allyn \& Bacon. 
INTERNATIONAL JOURNAL OF ACADEMIC RESEARCH IN BUSINESS AND SOCIAL SCIENCES

Vol. 9, No. 6, June, 2019, E-ISSN: 2222-6990 C 2019 HRMARS

McCroskey, J. C. (2005). An introduction to rhetorical communication. (9th ed.).Boston, MA: Allyn and Bacon.

Muhd Amirul, F. A. (2014). Graduan tempatan tidak mahir Bahasa Inggeris. Retrieved January 17, 2016, from http://plm.org.my/wrdp1/?p=2141

Mohd Sahandri, G. H., \& Saifuddin, K. A. (2009). Generic skills needed to produce human capital with 'first class mentality'. European Journal of Social Sciences, 10-1, 1-11.

Morshidi, S., Razak, A. A., \& Koo, Y. L. (2011). Trade in services and its policy implications: The case of cross-border/ transnational higher education in Malaysia. Journal of Studies in International Education, 15(3), 241-260.

Nabi, G. R., \& Bagley, D. (1998). Graduates' perceptions of transferable personal skills and future career preparation in the UK. Career Development International, 3(1), 31-39.

Noor Azina, I. (2011). Graduate characteristics and unemployment: A study among Malaysian graduate. International Journal of Business and Social Sciences, 2(6), 94-102.

Rahmah, I., Ishak, Y., \& Wei Sieng, L. (2011). Employers' perception on graduates in Malaysia service sector. International Business Management, 5(3), 184-193.

Roodt, J. (2005). Self-employment and the required skills. Management Dynamics, 14(1), 18-33.

Shuib, M. (2005). Preparing graduates for employment. Bulletin of Higher Education Research, 5(1), 1-7.

Siegal, G., \& Sorenson, J. (1994). What corporate America wants in entry-level accountants. Retrieved January 17, 2016, from

http://www.imanet.org/PDFs/Public/MAQ/2001_Q1/MAQ_Winter01_Univer

sityAcctProgram.pdf 